TITLE:

\title{
Source location and food availability determine the growth response of Orbicella faveolata to climate change stressors
}

\author{
Erica K. Towle ${ }^{* 1}$, Ana M. Palacio-Castro ${ }^{1}$, Andrew C. Baker ${ }^{1}$, Chris Langdon ${ }^{1}$ \\ ${ }^{1}$ Department of Marine Biology and Ecology, Rosenstiel School of Marine and Atmospheric \\ Science, University of Miami, 4600 Rickenbacker Cswy, Miami, FL 33149 \\ *Corresponding author: Erica K. Towle, etowle@ rsmas.miami.edu
}

Keywords: Corals, Climate Change, Florida Keys, Location Effects, Restoration Ecology

Abstract:

The local environment shapes coral physiology through acclimatization and also selects for genotypes best suited to a particular site. Both acclimatization and selection likely affect the response of corals to future climate change. The local environment is therefore an important factor to consider for restoration ecology. In this study, we exposed Orbicella faveolata from two different locations in Florida (Emerald Reef, near Key Biscayne in the upper Florida Keys, and Truman Harbor near Key West in the lower Florida Keys) that were commongardened for one month prior to experimentation to four temperature, $\mathrm{CO}_{2}$, and food availability treatments $\left(26^{\circ} \mathrm{C} / 390 \mathrm{ppm}, 26^{\circ} \mathrm{C} / 1000 \mathrm{ppm}, 31^{\circ} \mathrm{C} / 390 \mathrm{ppm}\right.$, and $31^{\circ} \mathrm{C} / 1000 \mathrm{ppm}$ where each of these treatments had fed and unfed components). The goal was to determine how the same species of coral from different locations would respond to projected climate change scenarios. We found that growth (measured as changes in buoyant weight) was highly correlated to source location (i.e., whether the corals came from Emerald Reef or Truman Harbor) and not to parent colony, and growth, symbiont density, chlorophyll $a$ content, and lipid content were highly correlated to feeding regime. These findings show that within a single reef tract, (i.e. the Florida Reef Tract), source location and food availability matter for the physiological outcome of a coral's stress response, and suggest that an explicit 
consideration of these effects may be important for management activities such as coral restoration, transplantation, and MPA placement.

Introduction:

Global climate change threatens reef-building corals and overall coral reef ecosystem health via ocean warming and ocean acidification. Ocean warming results in coral bleaching, whereby corals expel the symbiotic algae that live within them due to their narrow thermal tolerance (Glynn 2012). Under normal, unstressed conditions these symbionts can provide the coral with up to $95 \%$ of its daily metabolic requirements by transferring the products of photosynthesis to the coral host (Muscatine \& Porter 1977; Grottoli et al. 2006). When corals lose their symbiotic algae they lose their main source of nutrition, resulting in widespread mortality if bleaching is severe or prolonged. In addition to episodic bleaching events, the dissolution of anthropogenic $\mathrm{CO}_{2}$ in the ocean changes its carbonate chemistry, such that the $\mathrm{pH}$ of seawater decreases, resulting in ocean acidification (OA). This phenomenon impairs corals' ability to build their aragonitic skeletons (Chan \& Connolly 2013) and reduces their ability to sexually reproduce (Albright et al. 2010, 2011; Doropoulos \& Diaz-Pulido 2013). The negative effects of warming in combination with OA have been found to be additive or even synergistic on a variety of processes including calcification (Reynaud et al. 2003;

Albright \& Mason 2013; Kroeker et al. 2013). Coral heterotrophy, or the ability of the coral host to feed on its own from the water column on zooplankton or particulate organic matter as opposed to relying solely on photosynthetic product from its symbionts, has been shown to mitigate reductions in calcification due to thermal and/or OA stress (Grottoli et al. 2006; Cohen \& Holcomb 2010; Edmunds 2011; Towle et al. 2015a). Other indicators of resilience to climate change stress include past history of stress exposure (Carilli et al. 2012), the identity of the coral's algal symbionts or the relative abundance of algal to coral cells (Baker et al. 2004; Cunning \& Baker 2013), and/or its parental genotype (Baums et al. 2013). 
57 Confounding these potential indicators of resilience is the observation that even within the same coral colony, coral physiological metrics such as calcification rate, lipid content, and symbiont density can vary greatly (Teece et al. 2011). This natural variation makes it challenging to determine what affects the physiological outcome of a coral to multiple stressors.

The mountainous star coral, Orbicella faveolata, once a very common reef-building species in the Florida Reef Tract, was listed in 2014 as threatened under the U.S. Endangered Species Act (National Marine Fisheries Service 2014). The decline of reef-building species in Florida and elsewhere, and the recognition that they may not be able to recover naturally without human intervention, has prompted regional efforts to restore reefs through coral propagation and transplantation (Johnson et al. 2011; Young et al. 2012). Coral restoration in Florida has focused on Acropora cervicornis and to a lesser extent Acropora palmata, but attention is now being drawn to restoring other species, including slower-growing taxa with massive or submassive morphologies as part of a coral "landscaping" (vs. coral "gardening") approach (Forsman et al. 2015). However, outplanting success is variable, with numerous factors potentially determining success such as temperature, colony size, depth at the collection and transplant sites, and predation levels at the transplant site, to name a few (Johnson et al. 2011). Many of these factors have been poorly investigated, especially outside of the genus Acropora.

The major aims of this study were to investigate: (1) how colonies of $O$. faveolata from two different source sites in the lower and upper Florida Keys would respond to climate change stress, with special interest given to determining the relative importance of source location versus parent colony on the physiological responses of corals to stress; and (2) whether corals that had access to food would fare better than those that did not. We tested the hypothesis that there would be no difference in the calcification rate, lipid content, symbiont 
density, or chlorophyll content of $O$. faveolata colonies from the two sites, i.e., the variation in physiology would be due to stress treatment, and not source location or parent colony. The results of this study will help inform coral restoration efforts regarding using corals that may be physically distant from the restored site, and have implications for the assisted colonization of corals in anticipation of climate change.

Materials and Methods:

Collection

Colonies of Orbicella faveolata were collected using SCUBA from a depth of five meters at two sites in April 2014. Five medium-sized colonies were collected from Truman Harbor (TH), Key West, Florida (24.332 N, 81.484 W), under permit FKNMS-2014-064, and three large colonies were collected from Emerald Reef (ER), Key Biscayne, Florida (25.674 N, 80.099 W), under Florida Fish and Wildlife Special Activities License SAL-13-1182BSRP. The two sites are approximately 112 nautical miles distant from each other, and TH is a turbid site adjacent to an industrial port, whereas ER is a patch reef environment. Fifty cores from ER colonies ( $\sim 17$ per parent colony) and fifty cores from TH colonies ( $\sim 10$ per parent colony), each $2.5 \mathrm{~cm}$ in diameter, were made using a diamond tile drill bit (Montana MB65207). Cores were glued to numbered plastic tiles and allowed to recover under control conditions $\left(26^{\circ} \mathrm{C}, 390 \mathrm{ppm}\right)$ for one month prior to the start of the experiment.

\section{Experimental design}

Experimental corals were exposed to one of four experimental treatments: $26^{\circ} \mathrm{C} / 390$ $\operatorname{ppm}\left(\mathrm{LT}-\mathrm{LCO}_{2}\right), 26^{\circ} \mathrm{C} / 1000 \mathrm{ppm}\left(\mathrm{LT}-\mathrm{HCO}_{2}\right), 31^{\circ} \mathrm{C} / 390 \mathrm{ppm}\left(\mathrm{HT}-\mathrm{LCO}_{2}\right)$, and $31^{\circ} \mathrm{C} / 1000$ ppm $\left(\mathrm{HT}-\mathrm{HCO}_{2}\right)$ for a period of eight weeks from mid-June to mid-August 2014. Each treatment was replicated twice for a total of eight independently-controlled tanks. Each tank contained 12-14 corals, for a total of 100 cores. Within each tank, half of the corals were fed and half were unfed during the experiment (see below). Cores were evenly but haphazardly 
distributed between tanks accounting for source, i.e., half of the fed and unfed corals were from ER and half were from TH. Temperatures in the HT treatment were increased from ambient levels of $26^{\circ} \mathrm{C}$ to $31^{\circ} \mathrm{C}$ at a rate of $0.5^{\circ} \mathrm{C}$ per day. The target temperature $\left(31^{\circ} \mathrm{C}\right)$ is just above the mean local bleaching threshold in the Florida Keys $\left(30.4^{\circ} \mathrm{C}\right.$, Manzello et al. 2007), and the target $\mathrm{CO}_{2}$ level $(1,000 \mathrm{ppm})$ is the mid-point of the range of $\mathrm{CO}_{2}$ levels predicted for the end of the century (IPCC 2013). Experimental corals were maintained under naturally-variable solar irradiance in a greenhouse facility at the University of Miami's Experimental Hatchery in 60 L tanks replenished by a 250 L sump tank with complete water turnover every ten minutes. Each sump tank contained a heating and cooling element connected to a temperature controller (OMEGA CN7533) with accuracy $\sim 0.1^{\circ} \mathrm{C} . \mathrm{CO}_{2}$ levels were achieved by mixing pure $\mathrm{CO}_{2}$ and air using mass flow controllers (Sierra Instruments model 810C) that was pumped through a Venturi injector and circulated through the sump before being pumped into experimental tanks. The sump pump delivered pressurized water to a square of $1 / 2$ " PVC pipe with $1 / 8$ " holes drilled every 2 " that sits within the experimental tank and surrounds the corals. Therefore, water motion in the tank was turbulent, i.e. the corals experienced jets of water from four different directions. This was as close to natural as possible without creating oscillatory flow. All tanks were connected to a HOBO U30 data logger taking measurements of $\mathrm{CO}_{2}$, temperature, and light every five minutes. Daily PAR averaged throughout the experiment between 7:00am and 7:00pm was $350 \mu$ moles $\mathrm{m}^{-2} \mathrm{~s}^{-1}$. Fed corals were offered food ad libitum twice weekly using a powdered zooplankton diet (Ziegler's Larval AP 100) as in Towle et al. (2015a). Briefly, fed corals were placed in separate feeding bins to avoid contaminating treatment tanks containing unfed corals, and unfed corals were also put into separate bins, but without access to food, as a handling 
after sunset as in Grottoli et al. (2006) and all bins had pumps to ensure adequate water motion.

\section{$\underline{\text { Measurements }}$}

$250 \mathrm{~mL}$ water samples were taken from each tank weekly $(8$ tanks x 8 weeks $=64$ samples) to monitor seawater chemistry. Samples were poisoned with $100 \mu \mathrm{L}$ mercuric chloride for dissolved inorganic carbon (DIC) analysis. $\mathrm{CO}_{2}$ was measured using an equilibrator and LiCor $\mathrm{CO}_{2}$ analyzer system calibrated against 700 ppm pure $\mathrm{CO}_{2}$ gas.

Salinity was measured using a YSI meter calibrated before each use against a 50,000 microSiemen standard solution. DIC was measured in duplicate using a DIC analyzer (Apollo SciTech Inc.) standardized using certified reference materials obtained from Dr. A. Dickson (Scripps IO). Mean temperature, salinity, $\mathrm{pCO}_{2}$, and DIC were used to calculate $\mathrm{pH}$ (using the total scale) and aragonite saturation state $\left(\Omega_{\mathrm{a}}\right)$ for each treatment using the program $\mathrm{CO}_{2}$ SYS using $\mathrm{K}_{1}$ and $\mathrm{K}_{2}$ from Mehrbach et al. (1973) refit by Dickson \& Millero (1987) per Lewis \& Wallace (1998).

Calcification rates were measured biweekly as changes in coral weight in water using the buoyant weight technique according to Davies et al. (1989). A skeletal density of $1.95 \mathrm{~g}$ $\mathrm{cm}^{-3}$, based on four $O$. faveolata cores sacrificed at the beginning of the experiment, was used to calculate colony weight in air. Calcification rates were normalized to core surface area to permit reporting in ecologically relevant units, i.e., $\mathrm{mg} \mathrm{CaCO}_{3} \mathrm{~cm}^{-2} \mathrm{~d}^{-1}$.

At the end of the experiment, coral tissue was removed using a Water Pik following Szmant et al. (1990) in order to quantify symbiont density, chlorophyll $a$ content, and total lipid content. Of the total blastate volume, one $\mathrm{mL}$ was allocated for symbiont density, one $\mathrm{mL}$ was allocated for chlorophyll $a$, and five $\mathrm{mL}$ were allocated for total lipid content. For symbiont density, one $\mathrm{mL}$ was placed in a $1.5 \mathrm{~mL}$ Eppendorf tube with $50 \mu \mathrm{L}$ Lugols for later quantification using two replicates per sample read on a haemocytometer (Hausser 
Scientific). For chlorophyll $a$, one $\mathrm{mL}$ was filtered onto a glass fiber filter (GF/A) and stored at $-80^{\circ} \mathrm{C}$ until analysis. For analysis, filters were thawed to room temperature, placed in centrifuge tubes with eight $\mathrm{mL}$ methanol, and returned to $-80^{\circ} \mathrm{C}$ for forty-eight hours following Holm-Hansen and Riemann (1978). After forty-eight hours, samples were read on a fluorometer (TD-700 Turner Designs) calibrated with purified chlorophyll $a$ (SigmaAldrich catalog no. C6144). For total lipid content, five $\mathrm{mL}$ of blastate was filtered onto a glass fiber filter (GF/A) and stored at $-80^{\circ} \mathrm{C}$ until later analysis following Teece et al. (2011). Briefly, the five $\mathrm{mL}$ aliquot of total coral homogenate was extracted three times (four $\mathrm{mL}$ 1:1 dichloromethane:methanol). The resulting organic extracts were dried under a stream of surface area.

To identify and quantify the Symbiodinium types hosted by the corals, a small tissue 
were assessed for a tank effect (random factor), which was not significant. Four-way fullfactorial ANOVAs were run (temperature $\mathrm{x} \mathrm{CO}_{2} \mathrm{x}$ nutrition $\mathrm{x}$ site) with parent colony as a random factor for calcification, lipid content, symbiont density, and chlorophyll $a$. Alpha for all tests was set at 0.05 . Variations in coral physiology were also studied using multivariate techniques. A Standardized Principal Component Analysis (PCA) was performed in R v. 3.2.3 to examine the spatial structure of groups of samples depending on their calcification rate, lipid content, symbiont density, and chlorophyll $a$. Variables were centered and scaled to allow comparison between data with different units.

Results:

All of the colonies in this study except one from Emerald Reef were dominated by Symbiodinium clade D (> 90\%). Therefore, samples from that colony that were dominated by clade B and not D were removed from the analyses to avoid changes in physiology associated with hosting a different symbiont clade and not with the treatments. In the interest of full transparency of the limitations of this study, it should be noted that removing the particular ER colony that had $<90 \%$ D equated to removing 1-2 cores per tank, lowering statistical power, i.e. $10-12$ cores per tank and 5-6 per feeding regime. The authors note that it would be worthwhile to repeat this study using a larger sample size, as having to remove corals from the analyses was unforeseen. To date, there has only been one type of clade D (D1a, Symbiodinium trenchi) found in Caribbean scleractinian corals, so there was no concern regarding further sequencing (Pettay et al. 2015). However, Denaturing Gradient Gel Electrophoresis (DGGE) analyses of subsets of these samples were run and verified that the profiles of these clade D symbionts were all the same. Although the DGGE bands were not sequenced, they were characteristic of D1a. Mean seawater chemistry parameters from the duration of the study are summarized in Table 1. Temperatures from the collection sites from the collection month and summer months from 2011-2013 are shown in Table 2. During the month corals were collected, temperatures at Truman Harbor were approximately $1^{\circ} \mathrm{C}$ higher 

and 2011, corals at this site were exposed to temperatures above the bleaching threshold (Table 2). In contrast, the Emerald Reef site data suggest that during the previous two summers before collection, corals did not experience mean temperatures exceeding bleaching threshold (Table 2). Calcification rates were affected by $\mathrm{CO}_{2}$, nutrition, and site (Table 3, ANOVA, $\mathrm{p}<$ 0.05). On average, calcification rates were negative at $1,000 \mathrm{ppm}$ compared to positive at 390 ppm (Fig. 1a), negative when unfed compared to positive when fed (Fig. 1b), and negative at Emerald Reef compared to positive at Truman Harbor (Fig. 1c). Lipid content was significantly affected by nutrition, and on average unfed corals had $20 \%$ lower lipid content then fed corals (Table 3, ANOVA, p < 0.05, Fig. 2). Symbiont density was affected by temperature and nutrition, and on average corals had $25 \%$ fewer symbiont at $31^{\circ} \mathrm{C}$ than at $26^{\circ} \mathrm{C}$, and about $38 \%$ fewer symbionts when unfed compared to when fed (Table 3 , ANOVA, p $<0.05$, Fig. 3 a, b). Chlorophyll $a$ was affected by temperature, $\mathrm{CO}_{2}$, nutrition, and site $26^{\circ} \mathrm{C}, 17 \%$ lower at $1,000 \mathrm{ppm}$ compared to $390 \mathrm{ppm}, 43 \%$ lower when unfed compared to fed, and 30\% lower at Truman Harbor compared to Emerald Reef (Fig. 4 a, b, c, d). In the multivariate analyses, symbiont density, chlorophyll $a$ content, and (to a lesser extent) lipid content are reflected in $\mathrm{PC} 1\left(\cos ^{2}=0.91,0.88\right.$ and 0.60 respectively). This axis explains $61.5 \%$ of the variance and separates the fed corals (on the right of PC1, with higher scores for these three variables), from the starved corals (on the left, corresponding to lower symbiont density, chlorophyll $a$, and lipids, see Fig. 5). There was no clear separation between corals in different temperature or $\mathrm{CO}_{2}$ treatments, suggesting that feeding was the most important condition determining these physiological characteristics. Growth rate was reflected in PC2 $\left(\cos ^{2}=0.90\right)$ which explains $24.3 \%$ of the variance. This second axis 
separated the corals from TH (on the top of the axis, with higher calcification), from the ER corals (on the bottom of PC2, with lower growth rates, see Fig. 5a). This result indicated that even when $\mathrm{CO}_{2}$ significantly decreased calcification, the effect of site on growth rate was stronger than the effect of $\mathrm{CO}_{2}$ alone.

When the PCA objects map was visualized by parent colony instead of by location to address if the location effect was a generalization of the genotype effect, we did not find any aggregation of the samples due to parent colony, temperature, or $\mathrm{CO}_{2}$ treatment (Fig 5b). These observations together demonstrate the importance of heterotrophic feeding and source location shaping coral physiology.

\section{Discussion:}

In this study we found that in the mountainous coral (Orbicella faveolata) source location had a strong impact on how a coral responds to climate change stressors, even when corals were allowed to acclimate to the same conditions for a month prior to the onset of stress. This suggests that environmental history at different source locations in the Florida Reef Tract drives differences in coral physiology under stress. These effects were still detectable after one month of common gardening and two months of stress exposure. This finding has important implications for coral restoration because coral source location may play a major role in their future survivorship following outplanting.

We found that calcification rates were highly correlated with coral source location, but calcification rates in our study were lower than rates published in the field for O. faveolata ( 2.3-2.8 $\mathrm{mg} \mathrm{cm}^{-2} \mathrm{~d}^{-1}$, Mallela \& Perry 2007; Manzello et al. 2015a; Towle et al. 2015b). The lower calcification rates may be attributed to the fact that these were rates measured in a laboratory setting under projected climate change scenarios, whereas previous studies were conducted on unstressed corals. However, this does not explain why even the control group of corals from Emerald Reef had negative calcification rates, nor does it explain the differences observed between the two source locations in this study, which need to be 
addressed in the context of other physical and physiological parameters. Again, in the interest of full transparency of the limitations of the study, the negative calcification rates of some ER control corals suggest that one-month common gardening was not enough to alleviate the stress of coring and/or previous stress from the source site, and therefore it would be worthwhile to repeat this study to determine if the low rates were in fact representative of true responses. It also may be worth noting that the symbiont densities of unbleached $O$. faveolata in summer in this study $\left(\sim 1.5 \times 10^{6}\right.$ cells $\left.\mathrm{cm}^{-2}\right)$ were lower than unbleached $O$. faveolata in summer from a different study (i.e. $\sim 2.7$ x $10^{6}$ cells $\mathrm{cm}^{-2}$, Kemp et al. 2014,) which may account in part for the lower growth rates.

Nonetheless, previous work has demonstrated that variability in physiological response to climate change stress can sometimes be explained by host heterotrophy (Grottoli et al. 2006; Rodrigues \& Grottoli 2007; Cohen \& Holcomb 2010; Edmunds 2011; Towle et al. 2015a). While we did not assess host total biomass, i.e. total protein or ash-free dry weight, if there was a difference in host biomass between sites due to heterotrophic food availability, that could have also contributed to differences in growth rate. In this study, principle component analyses revealed that calcification, lipid content, symbiont density, and chlorophyll $a$ content were highly correlated with the ability of $O$. faveolata to feed. This observation is consistent with Towle et al. (2015a), who found that feeding and lipid content were correlated in another threatened Western Atlantic/Caribbean coral species, Acropora cervicornis. The present study also showed that the ability of corals to feed stimulates areal symbiont density and chlorophyll $a$ content, which is consistent with Ferrier-Pagès et al. (2003) and Houlbrèque et al. (2003, 2004a), providing further evidence that coral feeding may be a useful physiological health metric for restoration and reef resilience. Knowing that food availability enhances coral physiology under stress should incentivize reef managers to consider the level of natural zooplankton densities as a metric for determining MPA 
placement sites. Additionally, coral nursery operators may want to consider implementing supplemental feeding protocols for corals pre-outplanting.

While the results of the PCA agree with previous studies on the response of corals to stress, it remains unclear exactly why the two source locations show such dramatic differences in calcification rate. One explanation is that the warmer conditions in Truman Harbor acclimatized corals to higher temperatures. The summer before the corals were collected (2013), mean temperatures in June and July at TH were more than one degree higher than June and July 2013 mean temperatures at ER. Corals from TH also experienced mean summer temperatures in July and August of 2012 and July-September of 2011 greater than the bleaching threshold in the Florida Keys $\left(30.4^{\circ} \mathrm{C}\right.$, Manzello et al. 2007), yet appear to have been unaffected. Consequently, the high temperature used in our experiment $\left(31^{\circ} \mathrm{C}\right)$ likely stressed ER corals more than TH corals. This hypothesis is consistent with Oliver et al. $(2009,2011)$ who found that corals from warmer environments have higher resistance to bleaching temperatures, and can survive heat exposure that would bleach conspecifics from cooler microclimates. This may be because corals in warmer environments have higher baseline expression of genes involved in thermal stress response, such as heat shock proteins, antioxidant enzymes, and/or genes involved in apoptosis regulation and tumor suppression (Barshis et al. 2013). Variation in thermal tolerance may also be due in large part to variation in Symbiodinium types (Jones \& Berkelmans, 2011). However, in the case of this study, all corals had > 90\% clade D Symbiodinium, and those that did not were removed from analyses, and thus we can be fairly confident that symbiont clade type had no influence on the responses we observed. It is important to note that we had not been monitoring the types of zooxanthellae in these particular colonies over multiple years, so we do not have any idea how long D-dominance has persisted in these corals (see: Thornhill et al. 2006). As previously stated, finding a different type of $\mathrm{D}$ (other than $\mathrm{D} 1 \mathrm{a} / \mathrm{S}$. trenchi) would be very unusual since 
no other clade D symbionts have yet been found in Caribbean scleractinian corals. The idea that corals from different thermal histories have different bleaching thresholds is not novel; however, the fact that one month of acclimation to control conditions did not remove the effect of source location in $O$. faveolata suggests these findings could be the result of local selection and not acclimatization.

A second explanation, then, is that the higher mean summer temperatures at Truman Harbor selected for coral genotypes capable of dealing with relatively higher temperatures. This is supported by the fact that acclimation to $26^{\circ} \mathrm{C}$ for four weeks prior to the start of the experiment did not remove the effects of source location. Local selection at the two sites may have resulted in genotypic differences (fixed effects) that cannot be removed by common gardening. These fixed effects may constrain the ability of coral populations from different sites to acclimatize to changes in their environment (Palumbi et al. 2014). The hypothesis is then that these findings may not be the result of acclimatization, but may actually be because of different genes in the two different populations. One month does not appear long enough to remove this effect, and it is unclear what timescale could have removed the effects, e.g. maybe a more appropriate time frame would be on the order of several months to a year. Nonetheless, the data show very dramatic differences that are still apparent between the two populations with one site showing positive calcification and the other negative calcification across treatments. This finding is consistent with Howells et al. (2013) who found that while acclimatization processes are important in coping with small acute and seasonal temperature fluctuations, the thermal tolerance limits of the Pacific species Acropora millepora were determined primarily by genetic adaptation to local thermal regimes. Additionally, while this study is limited by the fact that sea water chemistry, turbidity, and water flow data were not available from either site, it is possible that the effects of local selection on TH corals may also allow them to calcify better under experimental $\mathrm{CO}_{2}$ stress, possibly due to higher food 
availability/POM and/or carbonate chemistry factors. These physiological mechanisms of environmental accommodation to acidification (Fabricius 2011; Shamberger et al. 2014) may be driven by genotypic differences among the two populations. Future work will need to assess the genotypes of $O$. faveolata at Truman Harbor and Emerald Reef, as we now have reason to believe that local selection could be driving the differences we observed in this study. While we have chosen to interpret our data as potential evidence of local selection, it should be stated that non-genetic physiological differences may be durable, in some cases even inherited, as suggested by Putnam and Gates (2015). Therefore, we cannot rule out potential acclimatization as another alternative hypothesis (other than adaptation) for the site differences found between these two sites, and follow-up work needs to be done to improve our understanding of these differences.

In conclusion, we found that source location and food availability may contribute to large variation in calcification response to climate change stressors in a threatened coral species from the Florida Reef Tract. These differences were not removed by one-month acclimation to the same control conditions, suggesting that they may be due to local selection at different sites. Because local selection is a fixed effect, source location may be a critical element in the success of long-term restoration efforts, since genotype by environment (GxE) interactions may play an important role in outplanting success. These findings also suggest that deliberate attempts to move corals from one thermal environment to another in preparation for climate change, even over short distances (i.e. within the Florida Keys) may have value, since the coral populations from different sites vary in their genetic make-up and are not simply acclimatized to different thermal regimes. However, these 'assisted colonization' (Kreyling et al. 2011) efforts should be tempered by investigations into the potential risks of genetic depression (van Oppen et al. 2014) or the introduction of pathogens or disease (Hoegh-Guldberg et al. 2008). 
Acknowledgements:

We are grateful to E. Bartels for help with the logistics of coral collection and for providing temperature data from the Truman Harbor site. We thank R. Pausch and D. Williams for temperature data from Emerald Reef. We also appreciate help from L. Hyder, C. Mor, and J. Fisch with tank maintenance. We thank the Florida Keys National Marine Sanctuary and the Florida Fish and Wildlife Conservation Commission for permitting this work to occur. ACB was supported by NSF OCE-1358699. Two reviewers helped improve the quality of this manuscript.

References:

Albright R, Mason B (2013) Projected near-future levels of temperature and $p \mathrm{CO}_{2}$ reduce coral fertilization success. PLoS ONE 8: e56468

Albright R, Langdon C (2011) Ocean acidification impacts multiple early life history processes of the Caribbean coral Porites astreoides. Glob Chang Biol 17: 2478-2487

Albright R, Mason B, Miller M, Langdon C (2010) Ocean acidification compromises recruitment success of the threatened Caribbean coral Acropora palmata. Proc Natl Acad Sci 107: 20400-20404

Baker AC, Rowan R, Knowlton N (1997) Symbiosis ecology of two Caribbean acroporid corals. Proc 8th Int Coral Reef Symp 2: 1295-1300

Baker AC, Starger CJ, McClanahan TR, Glynn PW (2004) Coral reefs: corals' adaptive response to climate change. Nature 430: 741

Barshis DJ, Ladner JT, Oliver TA, et al. (2013) Genomic basis for coral resilience to climate change. Proc Natl Acad Sci 110: 1387-1392

Baums IB, Devlin-Durante MK, Polato NR, Xu D, Giri S, Altman NS, Ruiz D, Parkinson JE, Boulay JN (2013) Genotypic variation influences reproductive success and thermal stress tolerance in the reef building coral, Acropora palmata. Coral Reefs 32: 703-717

Carilli J, Donner SD, Hartmann AC (2012) Historical temperature variability affects coral response to heat stress. PLoS ONE 7(3): e34418

Chan NCS, Connolly SR (2013) Sensitivity of coral calcification to ocean acidification: a meta-analysis. Glob Chang Biol 19: 282-290

Cohen A, Holcomb M (2010) Why corals care about ocean acidification: uncovering the mechanism. In: Scott D, Fabry V, Balch B, Feely R (eds) The Future of Ocean Biogeochemistry in a High $\mathrm{CO}_{2}$ World. Oceanography 22: 118-127

Cunning R, Baker AC (2013) Excess algal symbionts increase the susceptibility of reef corals to bleaching. Nat Clim Change 3: 259-262 
408

436

Cunning R, Silverstein RN, Baker AC (2015a) Investigating the causes and consequences of symbiont shuffling in a multi-partner reef coral symbiosis under environmental change. Proceedings of the Royal Society Series B 282: 20141725 doi: 10.1098/rspb.2014.1725

Cunning R, Vaughan N, Gillette P, Capo TR, Maté JL, Baker AC (2015b) Dynamic regulation of partner abundance mediates response of reef coral symbioses to environmental change. Ecology 96:1411-1420

Davies PS (1989) Short-term growth measurements of corals using an accurate buoyant weighing technique. Mar Biol 101: 389-395

Dickson AG, Millero FJ (1987) A comparison of the equilibrium constants for the dissociation of carbonic acid in seawater media. Deep Sea Research 34: 1733-1743

Doropoulos C, Diaz-Pulido G (2013) High $\mathrm{CO}_{2}$ reduces the settlement of a spawning coral on three common species of crustose coralline algae. Mar Ecol Prog Ser 475: 93-99

Edmunds PJ (2011) Zooplanktivory ameliorates the effects of ocean acidification on the reef coral Porites spp. Limnol Oceanogr 56: 2402-2410

Fabricius KE, Langdon C, Uthicke S, et al. (2011) Losers and winners in coral reefs acclimatized to elevated carbon dioxide concentrations. Nat Clim Change 1: 165-169

Ferrier-Pagès C, Witting J, Tambutté E, Sebens KP (2003) Effect of natural zooplankton feeding on the tissue and skeletal growth of the scleractinian coral Stylophora pistillata. Coral Reefs 22: 229-240

Forsman ZH, Page CA, Toonen RJ, Vaughan D (2015) Growing coral faster: micro-colonyfusion as a strategy for accelerating coral cover. PeerJ 3: DOI 10.7717/peerj.1313

Glynn PW (2012) Global warming and widespread coral mortality: evidence of first coral reef extinctions, pp. 103-119. Saving a Million Species. Springer.

Grottoli AG, Rodrigues LJ, Palardy JE (2006) Heterotrophic plasticity and resilience in bleached corals. Nature 440: 1186-1189

Hoegh-Guldberg, O., Hughes, L., McIntyre, S., Lindenmayer, D. B., Parmesan, C., Possingham, H. P., \& Thomas, C. D. 2008. Assisted colonization and rapid climate change. Science 321, 345-346.

Holmhansen O, Riemann B (1978) Chlorophyll $a$ determination- improvements in methodology. Oikos 30: 438-447

Houlbrèque F, Tambutté E, Ferrier-Pagès C (2003) Effect of zooplankton availability on the rates of photosynthesis, and tissue and skeletal growth in the scleractinian coral Stylophora pistillata. J Exp Mar Biol Ecol 296: 145-166 

zooplankton feeding, photosynthesis, and skeletal growth in the scleractinian coral Stylophora pistillata. J Exp Biol 207: 1461-1469

Howells EJ, Berkelmans R, van Oppen MJH, Willis BL, Bay LK (2013) Historical thermal regimes define limits to coral acclimatization. Ecology 94: 1078-1088

IPCC 2013: Summary for Policymakers. In: Climate Change 2013: The Physical Science Basis. Contribution of Working Group I to the Fifth Assessment Report of the Intergovernmental Panel on Climate Change [Stocker, T.F., D. Qin, G.-K. Plattner, M. Tignor, S. K. Allen, J. Boschung, A. Nauels, Y. Xia, V. Bex and P.M. Midgley (eds.)]. Cambridge University Press, Cambridge, United Kingdom and New York, NY, USA.

Johnson ME, Lustic C, Bartels E, Baums IB, Gilliam DS, Larson EA, Lirman D, Miller MW, Nedimyer K, Schopmeyer S (2011) Caribbean Acropora Restoration Guide: Best Practices for Propagation and Population Enhancement: 1 -64. http://nsuworks.nova.edu/occ_facreports/71

Jones AM, Berkelmans R (2011) Tradeoffs to thermalacclimation: Energetics and reproduction of a reef coral with heat tolerant Symbiodinium type D. J Mar Biol: 185890

Kemp DW, Hernandez-Pech X, Iglesias-Prieto R, Fitt WK, Schmidt GW (2014) Community dynamics and physiology of Symbiodinium spp. before, during, and after a coral bleaching event. Limnol Oceanogr 59: 788-797

Kreyling J, Bittner T, Jaeschke A, Jentsch A, Jonas Steinbauer M, Thiel D, \& Beierkuhnlein C (2011) Assisted colonization: a question of focal units and recipient localities. Restoration Ecology 19: 433-440

Kroeker KJ, Kordas RL, Crim R, Hendriks IE, Ramajo L, Singh GS, Duarte CM, Gattuso J-P (2013) Impacts of ocean acidification on marine organisms: quantifying sensitivities and interaction with warming. Glob Chang Biol 19: 1184-1896

Langdon C, Atkinson MJ (2005) Effect of elevated $\mathrm{pCO}_{2}$ on photosynthesis and calcification of corals and interactions with seasonal change in temperature/irradiance and nutrient enrichment. J Geophys Res-Oceans 110: 1-54

Lewis E, Wallace DWR (1998) CO2SYS-Program developed for the $\mathrm{CO}_{2}$ system calculations. Carbon Dioxide Inf. Anal. Center; Report ORNL/CDIAC-105. Oak Ridge National Laboratory, U.S. Department of Energy, Oak Ridge, Tennessee.

Mallela J, Perry CT (2007) Calcium carbonate budgets for two coral reefs affected by different terrestrial runoff regimes, Rio Bueno, Jamaica. Coral Reefs 26: 53-68

Manzello DP, Enochs IC, Kolodziej G, Carlton R (2015a) Recent decade of growth and calcification of Orbicella faveolata in the Florida Keys: An inshoreoffshore comparison. Mar Ecol Prog Ser 521: 81-89

Manzello DP, Berkelmans R, Hendee JC (2007) Coral bleaching indices and thresholds for the Florida Reef Tract, Bahamas, and St. Croix, US Virgin Islands. Marine Pollution Bulletin 54: $1923-1931$ 
Mehrbach C, Culberson CH, Hawley JE, Pytkowicz RM (1973) Measurement of the apparent dissociation constants of carbonic acid in seawater at atmospheric pressure. Limnol Oceanogr 18: 897-907

Muscatine L, Porter JW (1977) Reef corals: mutualistic symbioses adapted to nutrient-poor environments. Biosci 27: 454-460

National Marine Fisheries Service (2014) Endangered and threatened wildlife and plants: final listing determinations on proposal to list 66 reef-building coral species and to reclassify elkhorn and staghorn corals. Federal Register 79(135): 53852-54123

Oliver TA, Palumbi SR (2011) Do fluctuating temperature environments elevate coral thermal tolerance? Coral Reefs 30: 429-440

Oliver TA, Palumbi SR (2009) Distributions of stress-resistant coral symbionts match environmental patterns at local but not regional scales. Mar Ecol Prog Ser 378: 93-103

Palumbi SR, Barshis DJ, Traylor-Knowles N, Bay RA (2014) Mechanisms of reef coral resistance to future climate change. Science 344: 895-898

Pettay DT, Wham DC, Smith RT, Iglesias-Prieto R, LaJeunesse T (2015) Microbial invasion of the Caribbean by an Indo-Pacific coral zooxanthella. PNAS 112: 7513-7518

Putnam HM, Gates RD (2015) Preconditioning in the reef-building coral Pocillopora damicornis and the potential for trans-generational acclimatization in coral larvae under future climate changes scenarios. Jour Exp Biol 218: 2365-2372

Reynaud S, Leclercq N, Romaine-Lioud S, Ferrier-Pagès C, Jaubert J, Gattuso JP (2003) Interacting effects of $\mathrm{CO}_{2}$ partial pressure and temperature on photosynthesis and calcification in a scleractinian coral. Glob Chang Biol 9: 1660-1668

Rodrigues LJ, Grottoli AG (2007) Energy reserves and metabolism as indicators of coral recovery from bleaching. Limnol Oceanogr 52: 1874-1882

Shamberger KE, Cohen AL, Golbuu Y (2014) Diverse coral communities in naturally acidified waters of a Western Pacific reef. Geophys Res Lett 41: 499-504

Silverstein RN, Cunning R, Baker AC (2015) Change in algal symbiont communities after bleaching, not prior heat exposure, increases heat tolerance of reef corals. Global Change Biology 21: 236-249

Szmant AM, Gassman NJ (1990) The effects of prolonged bleaching on the tissue biomass and reproduction of the reef coral Montastraea annularis. Coral Reefs 8: 217-224

Teece MA, Estes B, Gelsleichter E, Lirman D (2011) Heterotrophic and autotrophic assimilation of fatty acids by two scleractinian corals, Montastraea faveolata and Porites astreoides. Limnol Oceanogr 56: 1285-1296 
537 Thornhill DJ, LaJeunesse TC, Kemp DW, Fitt WK, Schmidt GW (2006) Multi-year, seasonal

538 genotypic surveys of coral-algal symbioses reveal prevalent stability or post-bleaching

539 reversion. Mar Biol 148: 711-722

540 Towle EK, Enochs IC, Langdon C (2015a) Threatened Caribbean coral is able to mitigate the

541 adverse effects of ocean acidification on calcification by increasing feeding rate. PLoS ONE

542 10(4): e0123394

544 Towle EK, Carlton R, Langdon C, Manzello DP (2015b) In-situ measurement of metabolic

545 status in three coral species from the Florida Reef Tract. Regional Studies in Marine Science

546 2: $145-153$

547

548 van Oppen MJH, Puill-Stephan E, Lundgren P, De'ath G, Bay LK (2014) First-generation

549 fitness consequences of interpopulational hybridisation in a Great Barrier Reef coral and its

550 implications for assisted migration management. Coral Reefs 33: 607-611

551 Young CN, Schopmeyer SA, Lirman D (2012) A review of reef restoration and coral

552 propagation using the threatened genus Acropora in the Caribbean and Western Atlantic.

553 Bull of Mar Sci 88: 1075-1098

554 
Table 1 Mean seawater chemistry parameters during the study period presented as mean \pm 1 standard deviation where L stands for low, $\mathrm{H}$ stands for high, $\mathrm{T}$ stands for temperature in the treatment abbreviations, and DIC stands for dissolved inorganic carbon for $\mathrm{N}=64$ water samples. $\mathrm{pH}$ was measured using a total scale

$\begin{array}{lllllll}\text { Treatment } & \begin{array}{l}\text { Temperature } \\ \left({ }^{\circ} \mathrm{C}\right)\end{array} & \begin{array}{l}\mathrm{CO}_{2} \\ (\mathrm{ppm})\end{array} & \begin{array}{l}\text { Salinity } \\ (\mathrm{ppt})\end{array} & \mathrm{pH} & \Omega_{\mathrm{a}} & \begin{array}{l}\mathrm{DIC} \\ (\mu \mathrm{mol}\end{array} \\ \text { LT-LCO }_{2} & 26.2 \pm 0.12 & 387 \pm 21 & 33.9 \pm 1.20 & 8.08 \pm 0.02 & 3.89 \pm 0.18 & 2060 \pm 41 \\ \text { Hg-LCO }_{2} & 31.2 \pm 0.15 & 401 \pm 28 & 33.9 \pm 1.10 & 8.07 \pm 0.02 & 4.50 \pm 0.22 & 2034 \pm 34 \\ \text { LT-HCO }_{2} & 26.1 \pm 0.15 & 987 \pm 123 & 34.0 \pm 1.13 & 7.74 \pm 0.05 & 2.01 \pm 0.21 & 2216 \pm 38 \\ \text { HT-HCO }_{2} & 31.3 \pm 0.25 & 984 \pm 117 & 33.9 \pm 1.07 & 7.75 \pm 0.04 & 2.50 \pm 0.21 & 2203 \pm 44\end{array}$


560 Table 2 Mean temperature $\left({ }^{\circ} \mathrm{C} \pm 1 \mathrm{SD}\right)$ collected via $\mathrm{HOBO}$ temperature loggers at the two

561 source sites during the collection month and the warmest months of the year prior to coral

562 collection (June-September) from 2011-2013 where temperatures above mean local bleaching

563 threshold $\left(30.4^{\circ} \mathrm{C}\right.$, Manzello et al. 2007) are bolded

\begin{tabular}{lll}
\hline Month/Year & Emerald Reef & Truman Harbor \\
April 2014 (collection month) & $25.30 \pm 1.10$ & $26.50 \pm 1.40$ \\
June 2013 & $27.88 \pm 0.89$ & $29.61 \pm 1.19$ \\
July 2013 & $28.43 \pm 0.63$ & $29.81 \pm 0.93$ \\
August 2013 & $29.68 \pm 0.30$ & $30.34 \pm 0.56$ \\
September 2013 & $29.32 \pm 0.26$ & $29.96 \pm 0.61$ \\
June 2012 & $28.23 \pm 0.46$ & $29.61 \pm 1.19$ \\
July 2012 & $29.27 \pm 0.32$ & $\mathbf{3 0 . 6 2} \pm \mathbf{0 . 5 3}$ \\
August 2012 & $29.91 \pm 0.59$ & $\mathbf{3 1 . 1 2} \pm \mathbf{1 . 2 7}$ \\
September 2012 & $29.19 \pm 0.22$ & $30.19 \pm 0.90$ \\
June 2011 & $28.58 \pm 0.65$ & $30.09 \pm 1.39$ \\
July 2011 & $29.85 \pm 0.58$ & $\mathbf{3 1 . 4 3} \pm \mathbf{1 . 2 2}$ \\
August 2011 & $\mathbf{3 0 . 5 4} \pm \mathbf{0 . 3 4}$ & $\mathbf{3 1 . 8 2 \pm 0 . 5 5}$ \\
September 2011 & $30.29 \pm 0.40$ & $\mathbf{3 1 . 0 1 \pm 0 . 5 5}$
\end{tabular}


565 Table 3 Effect tests for calcification rate, lipid content, symbiont density, and chlorophyll $a$ 566 for Emerald Reef and Truman Harbor where significant $p$ values are bolded for $p<0.05$ 567 where $\mathrm{T}=$ temperature, $\mathrm{CO} 2$ = carbon dioxide, and $\mathrm{N}=$ nutritional status (fed or starved)

\section{Calcification rate}

\begin{tabular}{lllccc}
\hline Source & Nparm & DF & DFDen & F ratio & Prob > F \\
\hline T & 1 & 1 & 62.16 & 1.1710 & 0.2834 \\
\hline $\mathbf{C O 2}$ & 1 & 1 & 59.55 & 13.9162 & $\mathbf{0 . 0 0 0 4}$ \\
\hline $\mathbf{T} * \mathbf{C O 2}$ & 1 & 1 & 59.54 & 1.4632 & 0.2312 \\
\hline Nutrition & 1 & 1 & 59.07 & 18.8285 & $<.0001 *$ \\
\hline T*Nutrition & 1 & 1 & 60.79 & 0.0666 & 0.7972 \\
\hline $\mathbf{C O 2}$ Nutrition & 1 & 1 & 59.02 & 0.3219 & 0.5726 \\
\hline T*CO2*Nutrition & 1 & 1 & 59.50 & 0.2479 & 0.6204 \\
\hline Site & 1 & 1 & 3.381 & 27.2310 & $\mathbf{0 . 0 1 0 1} *$ \\
\hline T*Site & 1 & 1 & 62.16 & 0.8138 & 0.3705 \\
\hline CO2*Site & 1 & 1 & 59.55 & 0.4244 & 0.5172 \\
\hline T*CO2*Site & 1 & 1 & 59.54 & 0.2665 & 0.6076 \\
\hline Nutrition*Site & 1 & 1 & 59.07 & 0.0746 & 0.7858 \\
\hline T*Nutrition*Site & 1 & 1 & 60.79 & 0.4382 & 0.5105 \\
\hline CO2*Nutrition*Site & 1 & 1 & 59.02 & 0.3740 & 0.5432 \\
\hline T*CO2*Nutrition*Site & 1 & 1 & 59.50 & 0.1015 & 0.7511 \\
\hline
\end{tabular}

\begin{tabular}{lllrrr}
\hline Lipids & & & & & \\
\hline Source & Nparm & DF & DFDen & F ratio & Prob > F \\
\hline $\mathbf{T}$ & 1 & 1 & 64.00 & 0.4419 & 0.5086 \\
\hline $\mathbf{C O 2}$ & 1 & 1 & 61.05 & 1.8721 & 0.1763 \\
\hline $\mathbf{T}$ CO2 & 1 & 1 & 61.07 & 2.4811 & 0.1204 \\
\hline Nutrition & 1 & 1 & 60.37 & 4.6022 & $\mathbf{0 . 0 3 6 0}$ \\
\hline $\mathbf{T} *$ Nutrition & 1 & 1 & 62.14 & 0.0001 & 0.9928 \\
\hline $\mathbf{C O 2}$ Nutrition & 1 & 1 & 60.40 & 0.7636 & 0.3857 \\
\hline $\mathbf{T} * \mathbf{C O 2} *$ Nutrition & 1 & 1 & 61.58 & 1.2774 & 0.2628 \\
\hline Site & 1 & 1 & 3.764 & 3.2099 & 0.1521 \\
\hline $\mathbf{T} *$ Site & 1 & 1 & 64.00 & 1.1827 & 0.2809 \\
\hline $\mathbf{C O 2}$ Site & 1 & 1 & 61.05 & 1.9860 & 0.1638 \\
\hline $\mathbf{T} * \mathbf{C O 2} *$ Site & 1 & 1 & 61.07 & 2.7745 & 0.1009 \\
\hline Nutrition*Site & 1 & 1 & 60.37 & 2.1938 & 0.1438 \\
\hline $\mathbf{T} *$ Nutrition*Site & 1 & 1 & 62.14 & 0.2866 & 0.5943 \\
\hline CO2*Nutrition*Site & 1 & 1 & 60.40 & 0.0680 & 0.7952 \\
\hline $\mathbf{T} * \mathbf{C O 2} *$ Nutrition*Site & 1 & 1 & 61.58 & 0.0243 & 0.8766 \\
\hline
\end{tabular}

\section{Chlorophyll $a$}

\begin{tabular}{lllrcc}
\hline Source & Nparm & DF & DFDen & F ratio & Prob > F \\
\hline T & 1 & 1 & 63.22 & 13.4823 & $\mathbf{0 . 0 0 0 5 *}$ \\
\hline CO2 & 1 & 1 & 59.53 & 6.3284 & $\mathbf{0 . 0 1 4 6 *}$ \\
\hline T*CO2 & 1 & 1 & 59.52 & 0.0083 & 0.9275 \\
\hline Nutrition & 1 & 1 & 58.81 & 55.9392 & $<.0001 *$ \\
\hline T*Nutrition & 1 & 1 & 61.05 & 2.1128 & 0.1512 \\
\hline CO2*Nutrition & 1 & 1 & 58.72 & 0.3733 & 0.5436 \\
\hline
\end{tabular}




\begin{tabular}{lllccc}
\hline T*CO2*Nutrition & 1 & 1 & 59.46 & 0.6482 & 0.4240 \\
\hline Site & 1 & 1 & 2.939 & 10.5351 & $\mathbf{0 . 0 4 9 0 *}$ \\
\hline T*Site & 1 & 1 & 63.22 & 1.5741 & 0.2142 \\
\hline CO2*Site & 1 & 1 & 59.53 & 0.0002 & 0.9902 \\
\hline T*CO2*Site & 1 & 1 & 59.52 & 0.2665 & 0.6076 \\
\hline Nutrition*Site & 1 & 1 & 58.81 & 1.9560 & 0.1672 \\
\hline T*Nutrition*Site & 1 & 1 & 61.05 & 1.8145 & 0.1829 \\
\hline CO2*Nutrition*Site & 1 & 1 & 58.72 & 2.0049 & 0.1621 \\
\hline T*CO2*Nutrition*Site & 1 & 1 & 59.46 & 0.8749 & 0.3534 \\
\hline
\end{tabular}

\section{Zooxanthellae density}

\begin{tabular}{lllrrr}
\hline Source & Nparm & DF & DFDen & F ratio & \multicolumn{1}{c}{ Prob > F } \\
\hline T & 1 & 1 & 40.80 & 13.3886 & $\mathbf{0 . 0 0 0 7} *$ \\
\hline CO2 & 1 & 1 & 63.13 & 1.6001 & 0.2105 \\
\hline T*CO2 & 1 & 1 & 63.30 & 0.0491 & 0.8254 \\
\hline Nutrition & 1 & 1 & 60.37 & 52.8440 & $<.0001 *$ \\
\hline T*Nutrition & 1 & 1 & 63.10 & 2.0640 & 0.1558 \\
\hline CO2*Nutrition & 1 & 1 & 59.73 & 1.6065 & 0.2099 \\
\hline T*CO2*Nutrition & 1 & 1 & 63.19 & 0.1713 & 0.6804 \\
\hline Site & 1 & 1 & 0.753 & 30.6812 & 0.1700 \\
\hline T*Site & 1 & 1 & 40.80 & 2.1694 & 0.1485 \\
\hline CO2*Site & 1 & 1 & 63.13 & 0.0942 & 0.7599 \\
\hline T*CO2*Site & 1 & 1 & 63.30 & 0.0114 & 0.9154 \\
\hline Nutrition*Site & 1 & 1 & 60.37 & 0.0806 & 0.7775 \\
\hline T*Nutrition*Site & 1 & 1 & 63.10 & 2.7342 & 0.1032 \\
\hline CO2*Nutrition*Site & 1 & 1 & 59.73 & 2.1953 & 0.1437 \\
\hline T*CO2*Nutrition*Site & 1 & 1 & 63.19 & 2.1848 & 0.1443 \\
\hline
\end{tabular}

569 Figure legends:

570 Fig. 1 Calcification rates of $O$. faveolata pooled by levels based on significant main effects

571 from ANOVA analyses where panel A shows the $\mathrm{CO}_{2}$ effect, panel B shows the nutrition

572 effect, and panel $\mathrm{C}$ shows the site effect. Error bars represent \pm 1 S.E. Total $\mathrm{N}=$

573 approximately 100 cores.

574 Fig. 2 Lipid content of $O$. faveolata pooled by levels based on the significant main effect of

575 nutrition from ANOVA analyses. Error bars represent \pm 1 S.E. Total $\mathrm{N}=$ approximately 100

576 cores. 
577 Fig. 3 Symbiont density of $O$. faveolata pooled by levels based on significant main effects of 578 from ANOVA analyses where panel A shows the temperature effect and panel B shows the 579 nutrition effect. Error bars represent \pm 1 S.E. Total $N=$ approximately 100 cores.

580 Fig. 4 Chlorophyll $a$ content of $O$. faveolata pooled by levels based on significant main 581 effects from ANOVA analyses where panel A shows the temperature effect, panel B shows 582 the $\mathrm{CO}_{2}$ effect, panel $\mathrm{C}$ shows the nutrition effect, and panel D shows the site effect. Error 583 bars represent \pm 1 S.E. Total $\mathrm{N}=$ approximately 100 cores.

584 Fig. 5 Ordination of approximately 100 coral cores by principle component analysis (PCA) 585 based on coral physiology (growth rate, chlorophyll $a$ content, zooxanthellae density, and 586 lipid content). In 5A and 5B each point represents a coral core, and proximity between the 587 points indicates physiological similarity. Point size represents the contribution of each core to the PCA $\left(\mathrm{Cos}^{2}\right)$. The legend in $2 \mathrm{C}$ shows the direction of the variables in the PCA in both panel A and B. The lengths of vectors indicate the contribution of the descriptors to the

590 formation of PC1 and PC2. Chlorophyll $a$ content (Chl), zooxanthellae density (ZooDen), 591 and lipid content (Lipids) were highly correlated between them, and not correlated with growth rate (Growth). 

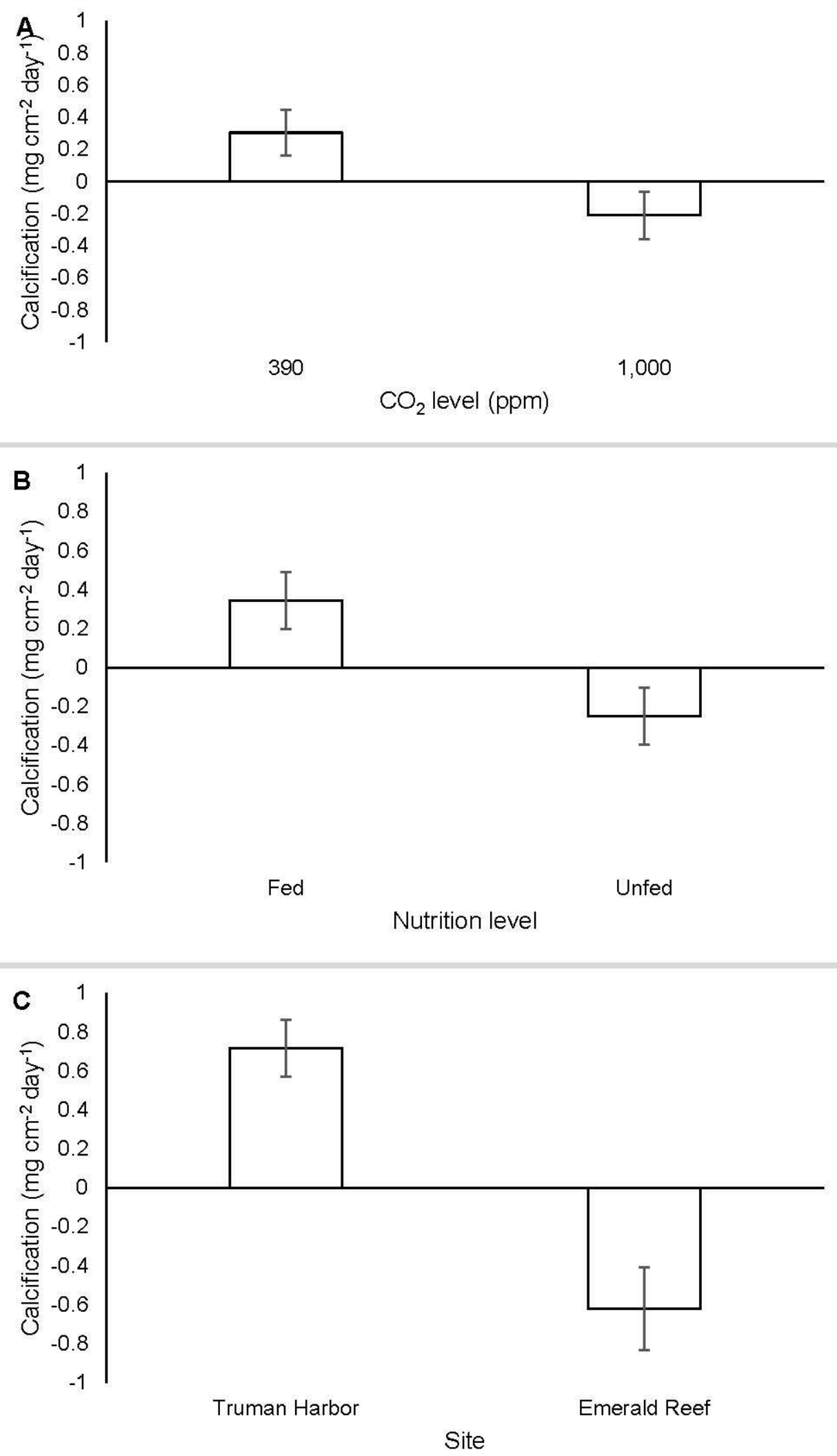


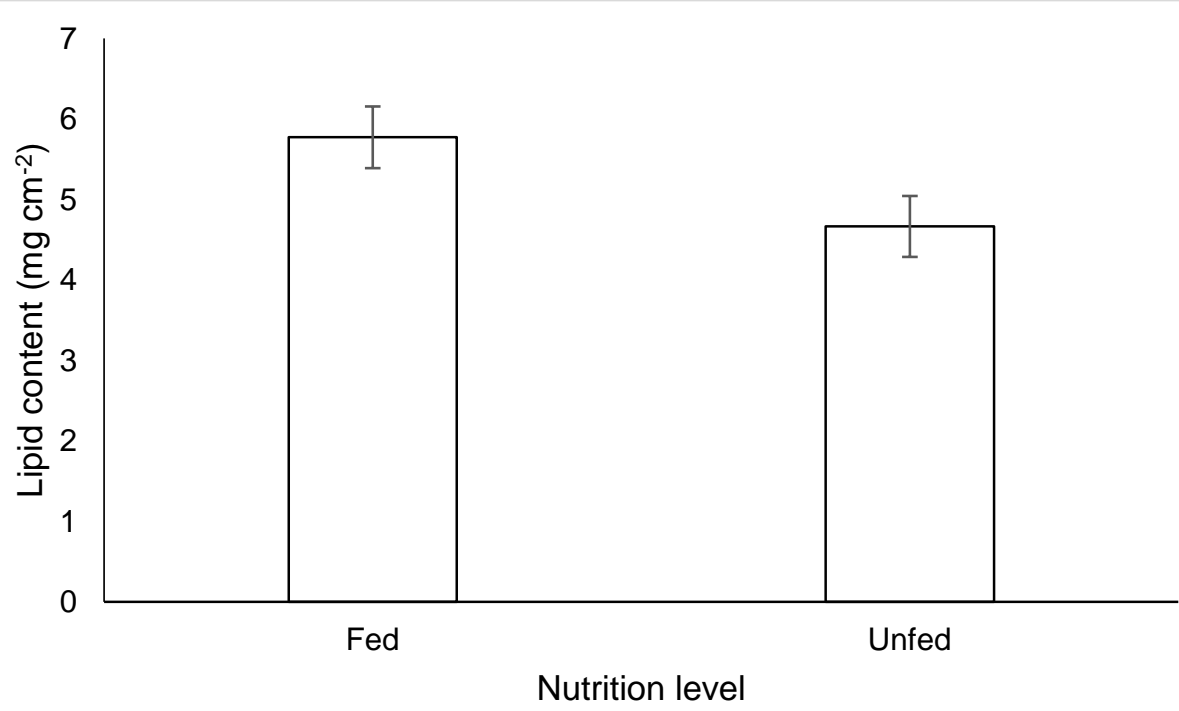

596

597 Figure 2 

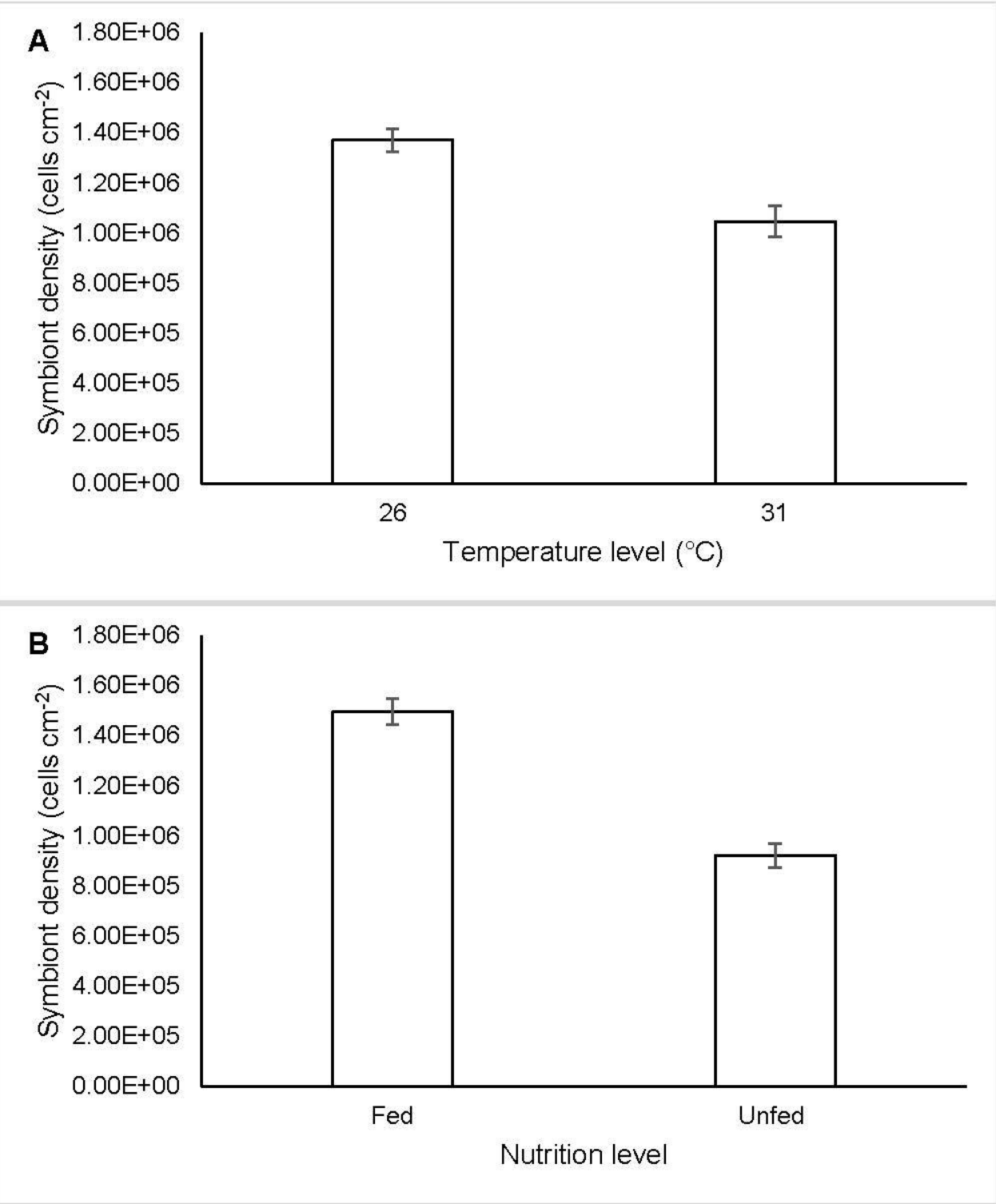

598

Figure 3 

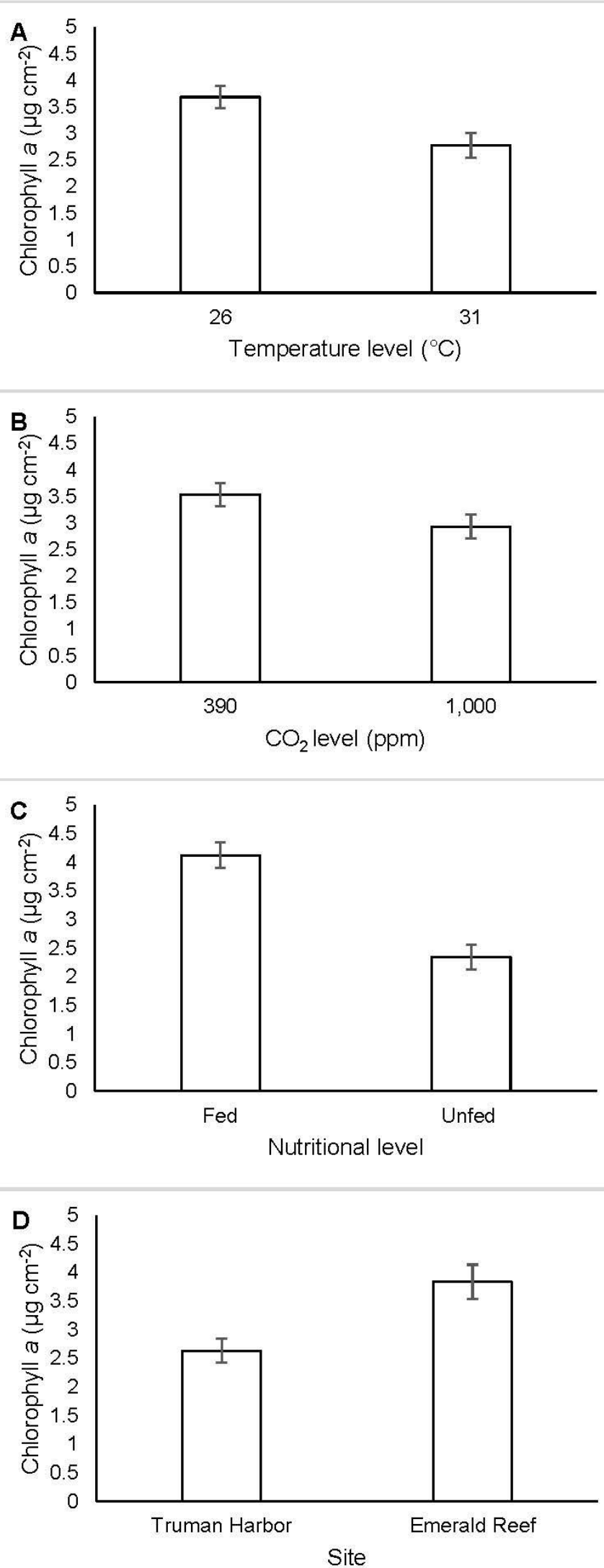

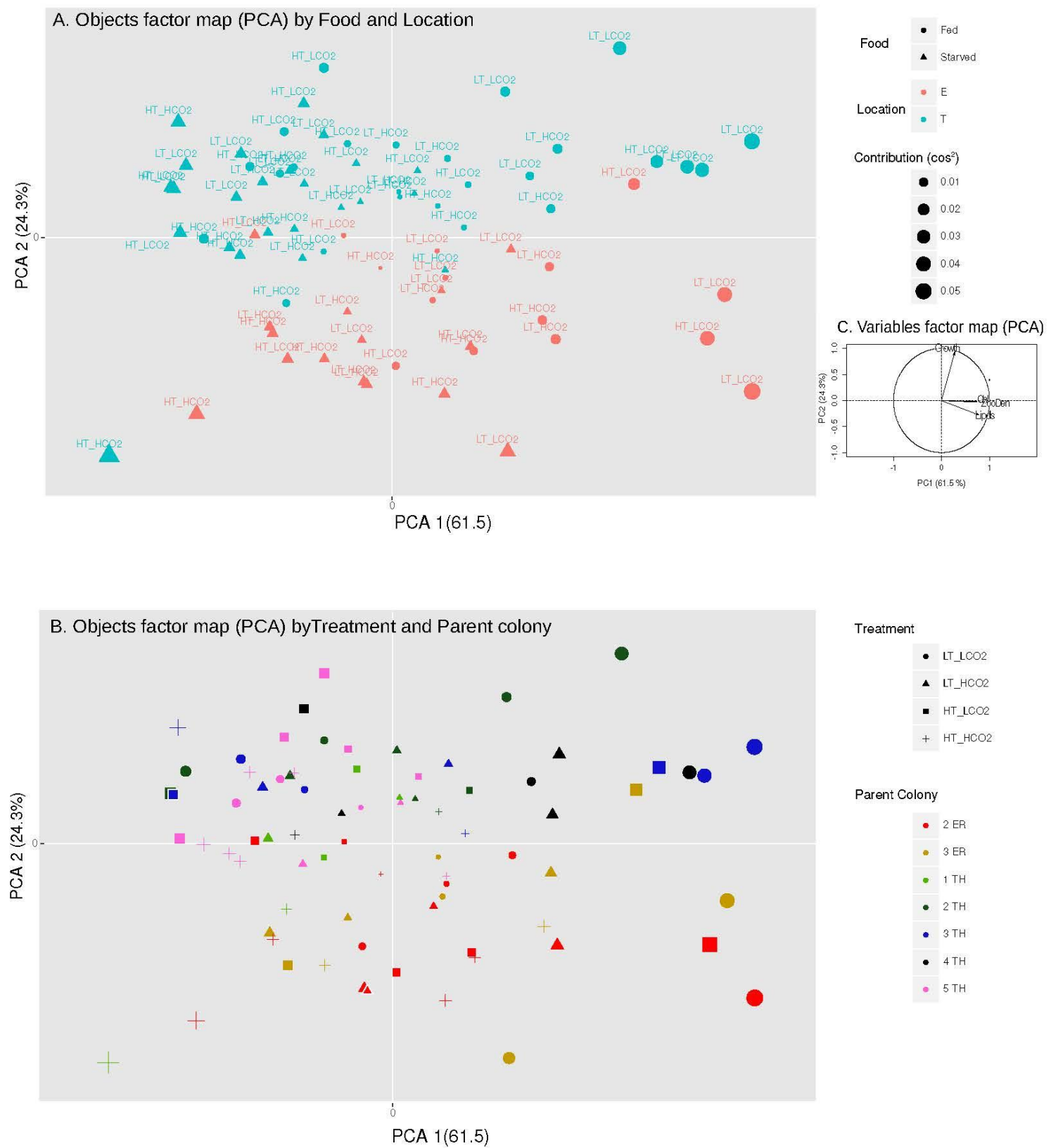

Figure 5 